\title{
Nutritional value and safety of castor bean (Ricinus communis) seeds detoxified in solid-state fermentation by Pleurotus ostreatus
}

\author{
OLUWAFOLAKEMI CHRISTIANAH ADEBAYO ${ }^{1}$, CLEMENT OLUSOLA OGIDI ${ }^{1,2 \bullet}$, \\ BAMIDELE JULIET AKINYELE ${ }^{1}$ \\ ${ }^{1}$ Department of Microbiology, Federal University of Technology. PMB704, Akure, Nigeria. "email: clementogidi@yahoo.com \\ ${ }^{2}$ Biotechnology Unit, Department of Biological Sciences, Kings University. PMB 555, Odeomu, Nigeria
}

Manuscript received: 25 January 2019. Revision accepted: 10 June 2019.

\begin{abstract}
Adebayo OC, Ogidi CO, Akinyele BJ. 2019. Nutritional value and safety of castor bean (Ricinus communis) seed detoxified in solid-state fermentation by Pleurotus ostreatus. Biofarmasi J Nat Prod Biochem 17: 55-64. The nutrient and antinutrient contents of unfermented castor seeds (UCS), castor seeds fermented with Pleurotus ostreatus (CPF), and "Ogiri," a naturally fermented condiment from castor seeds (CSF), were determined. Proximate analyses of all the samples were carried out using methods of the Association of Official Agricultural Chemists. The safety of the samples was carried out using an animal model. The raw castor seeds (UCS) had the highest carbohydrates $(61.04 \%)$, ash $(6.02 \%)$, fat $(6.65 \%)$, fiber $(6.62 \%)$, and calcium $(0.30 \mathrm{mg} / 100 \mathrm{~g})$. Castor seeds fermented with Pleurotus ostreatus (CPF) had the highest protein content of $20.47 \%$, magnesium of $7.16 \mathrm{mg} / 100 \mathrm{~g}$, alkaloids $(7.40 \mathrm{mg} / \mathrm{g}$ ), and saponins $(6.69 \mathrm{mg} / \mathrm{g})$. CSF had the highest zinc $(0.69 \mathrm{mg} / 100 \mathrm{~g})$. CPF had the lowest tannin $(0.05 \mathrm{mg} / \mathrm{g})$. The essential amino acids increased significantly $(\mathrm{p}<0.05)$ in the fermented samples. Tryptophan was absent in UCS but present in CSF and CPF with values of 0.78 $\mathrm{mg} / 100 \mathrm{~g}$ and $1.15 \mathrm{mg} / 100 \mathrm{~g}$, respectively. The hematological analysis of the rats fed CPF had the highest WBC of $5.43 \times 10^{9}$, which indicated a positive immunomodulatory effect. Hence, this study revealed that Pleurotus ostreatus degraded the toxic compounds in castor seeds to a large extent and enhanced the nutritional contents of the final product.
\end{abstract}

Keywords: Castor seeds, fermentation, hematological analysis, nutrients, Pleurotus ostreatus

\section{INTRODUCTION}

Natural toxins produced by plants are secondary metabolites that protect them from various threats from microorganisms, insects, and predators (Singh et al., 2013). Many plants contain natural toxins, such as bitter apricot seeds, bamboo shoots, cassava, flaxseeds, potatoes, wild mushroom, green beans, red and white kidney beans, and castor seeds (RAS 2007). These toxins, namely; cyanogenic glycosides, glycoalkaloids, muscarine, and lectins, may be found throughout the whole plant or in some parts of the plants (seeds, fruits, and leaves). These toxins could be harmful to human health when ingested in a significant amount or when raw materials are not processed properly into final food products.

The Castor oil plant (Ricinus communis) belongs to the family of Euphorbiaceae and grows throughout tropical and sub-tropical regions of the world (Ojinnaka et al., 2013; Sousa et al., 2017). Castor seed is a poisonous seed of the castor oil plant ( $R$. communis). The castor seed is inedible because the seed contains a toxic protein, ricin, and other toxic constituents such as ricinine and ricinoleic acids (Madeira Jr. et al., 2011). The presence of toxic components in castor seeds has remained a serious impediment to the consumption of castor seeds. Various detoxification methods have been used with varying degrees of success and limitations (Akande et al., 2016). From an economic point of view, these processes are still not practical and not efficient enough to be applied on a large scale.

Fermentation is one of the oldest forms of biotechnology that uses microorganisms to produce secondary metabolites and recombinant products on an industrial scale (Paulová et al., 2016). The fermentation processes can also enhance food safety by reducing toxic compounds during the production process. Some examples of traditionally fermented condiments produced by solidsubstrate fermentation are "Iru" from soya beans (Glycine max), Bambara nut (Vigna subterrenea), African locust bean (Parkia biglobosa), "Okpehe" from African Mesquite seeds (Prosopis Africana), "Ugba" from oil bean seed (Pentaclethra macrophylla) and "Ogiri" from melon seeds (Cucumeropsis mannii) or castor seeds (Ricinus communis)

In Nigeria, 'Ogiri,' a condiment from fermented castor seeds, has a characteristic ammoniacal odor, and its flavor enhances the taste of traditional soups and sauces (Omafuvbe et al. 2004). It serves as a supplement, a nutritious non-meat protein substitute, and a functional ingredient in soup. Although most of the condiments constitute a significant nutritional proportion of diet for many people, there are still a lot of challenges associated with their products, such as long hours of boiling, recurrent boiling before the fermentation, having a short shelf life, less acceptable packaging materials, and the typical putrid odor (Ishiwu et al. 2015). Therefore, a new method needs to be introduced by utilizing microorganisms (fungi) to make it easier to reduce toxins in the substrate. The use of 
fungi for eliminating toxins has been adopted in several traditional foods to facilitate the production process.

Some fermented foods have been known in several countries. Aidoo et al. (2006) used Aspergillus oryzae for the fermentation process of rice before introducing other yeast to produce Sake (rice wine). 'Tempeh,' traditional food from Indonesia, was produced by fermenting cooked soybeans with a fast-growing fungus: Rhizopus oligosporus (Iljas et al. 1973). Soy sauce, a condiment made from wheat and soybeans, was fermented with Aspergillus spp., yeasts, and lactic acid bacteria. 'Furu,' a condiment side dish consisting of soya bean curd fermented and partly degraded by the mold; Actinomucor elegans (Nout and Aidoo 2011). Fungi such as P. ostreatus possess several lignocellulolytic enzymes (laccase, manganese peroxidase, cellulase, and xylanase), selectively used to degrade the toxic compounds in some crops (da Luz et al. 2014). Since $P$. ostreatus can be tagged as a Generally recognized as safe (GRAS) fungus, it is a non-pathogenic microorganism. It is commonly used to degrade and detoxify food crops before consumption. Therefore, this study was designed to detoxify castor seeds using $P$. ostreatus in solid-state fermentation and enhance the by-product's nutritional properties.

\section{MATERIALS AND METHODS}

\section{Collection of castor seeds}

Castor seeds were obtained from Akure main market. The raw castor seeds were dehulled, sorted out to remove unwanted materials, and dried at $27^{\circ} \mathrm{C}$ for 7 days. 'Ogiri,' a locally fermented condiment from castor seeds (CSF), was purchased.

\section{Fungal cultivation}

The spawn of Pleurotus ostreatus was obtained from the Federal Institute of Industrial Research, Oshodi (FIIRO), Lagos. The spawn was inoculated into Potato Dextrose Agar (PDA) plate and incubated for seven days at $25^{\circ} \mathrm{C}$.

\section{Fermentation of castor seeds with Pleurotus ostreatus}

The dehulled castor seeds were divided into two portions. The first portion was boiled for 1 hour, while the second portion was not boiled and left unfermented (UCS). Four agar discs $(6 \mathrm{~mm})$ of Pleurotus ostreatus mycelia were inoculated into sterile Potato dextrose broth $(20 \mathrm{ml})$ and left for seven days at $25^{\circ} \mathrm{C}$. After that, the broth was aseptically introduced to boiled castor seeds (500 g) and left to ferment for five days using solid-state fermentation. After fermentation, the castor seeds (CPF) were mashed into paste and oven-dried at $28^{\circ} \mathrm{C}$ for 4 hours.

\section{Proximate analysis of unfermented and fermented castor seeds}

Proximate analysis of raw and fermented castor seeds was determined using the method of the Association of Official Analytical Chemists (AOAC) (2016).

The sample's moisture was determined by drying $2 \mathrm{~g}$ of the sample in the oven at $105^{\circ} \mathrm{C}$ for 3 hours.
$\%$ Moisture content $=\underline{\mathrm{W}}_{2}-\mathrm{W}_{3} \underline{\underline{3}} \times 100$

$$
\mathrm{W}_{2}-\mathrm{W}_{1}
$$

Where, $\mathrm{W}_{1}=$ Weight of crucible; $\mathrm{W}_{2}=$ Weight of crucible + sample before drying; $\mathrm{W}_{3}=\mathrm{Weight}$ of crucible + sample after drying

The ash content of the sample was determined by incinerating $5.0 \mathrm{~g}$ of sample in a muffle furnace at $550^{\circ} \mathrm{C}$ for $24 \mathrm{~h}$.

$$
\% \text { Total ash }=\frac{\mathrm{W}_{5}-\mathrm{W}_{6}}{\mathrm{~W}_{4}} \times 100
$$

Where, $\mathrm{W}_{4}=$ Weight of sample before ashing $(\mathrm{g}) ; \mathrm{W}_{5}=$ Weight of dish + sample after ashing; $\mathrm{W}_{6}=$ Weight of empty dish

The fat content was determined by extracting fat from samples using n-hexane in a Soxhlet extractor. Briefly, $2 \mathrm{~g}$ of sample was wrapped in a filter paper and gradually lowered in the thimble with a fitted flask containing nhexane. The round-bottomed flask in a Soxhlet extraction unit was slowly heated with a thermostatically controlled mantle. The solvent evaporated and passed through the sides tube of the extract to the reflux condenser. The filter paper with the defatted sample was removed from the extractor, and the refluxed solvent was distilled out and recovered.

$$
\% \text { Crude fat }=\frac{\mathrm{W}_{2}}{\mathrm{~S}}-\underline{\mathrm{W}_{1}} \times 100
$$

Where, W1=Weight of empty evaporating dish; W2= Weight of evaporating dish + content after drying; $\mathrm{S}=$ Weight of the sample after drying.

The protein content was determined using the Kjeldahl nitrogen method. The sample $(2.0 \mathrm{~g})$ was weighed into the digesting flask. Kjeldahl catalyst and $20 \mathrm{ml}$ of concentrated $\mathrm{H}_{2} \mathrm{SO}_{4}$ were added to the sample and then fixed in the digestion unit $\left(450^{\circ} \mathrm{C}\right)$ of the Kjeldahl apparatus in a fume cupboard for 8 hours. After reaching room temperature, boric acid ( $20 \mathrm{ml}$ of $4 \%$ ) was pipetted into a conical flask. A drop of methyl red was added to the flask as an indicator. The sample was diluted with $75 \mathrm{ml}$ of distilled water made alkaline with $20 \mathrm{ml}$ of $\mathrm{NaOH}(20 \%)$ and distilled. The steam exit of the distillatory was closed, and the change in color of boric acid to green was timed. The mixture was distilled for $15 \mathrm{~min}$. The filtrate was then titrated against $0.1 \mathrm{~N} \mathrm{HCl}$. The equation calculated the protein content $(\%$ of Protein) :

$\%$ Protein content $=$ nitrogen content $\times 6.25$.

Fiber content was determined using acid and alkaline digestion methods with $20 \% \mathrm{H}_{2} \mathrm{SO}_{4}$ and $\mathrm{NaOH}$ solution.

$$
\% \text { Fiber content }=\underline{\mathrm{W}_{2}} \underset{\mathrm{W}_{1}}{\mathrm{~W}_{3}} \times 100
$$

Carbohydrate content was determined by the difference method with the equation as follows: 
Carbohydrates $(\%)=100-(\%$ moisture $+\%$ protein $+\%$ fat $+\%$ crude fiber $+\%$ ash)

\section{Mineral analysis of unfermented and fermented castor seeds}

AOAC (2013) method was used to determine the mineral composition of the unfermented and fermented castor seeds. Two $\mathrm{g}$ of sample was weighed into a crucible and heated in a muffle furnace at $550^{\circ} \mathrm{C}$ for 6 hours. The ash was cooled, and $6 \mathrm{~N} \mathrm{HCl}$ was added. The mixture was boiled for $10 \mathrm{~min}$, cooled, and filtered into a $100 \mathrm{ml}$ volumetric flask. The crucible was washed with distilled water, added the filtrate was put into a $100 \mathrm{ml}$ volumetric flask. The volume was made to $100 \mathrm{ml}$ with distilled water. An aliquot of the filtrate was aspirated into the Atomic Absorption Spectrophotometer (Pye Unicam). The absorbance values corresponding to the different minerals were recorded against standard solutions of $\mathrm{Ca}, \mathrm{Mg}, \mathrm{Mn}$, $\mathrm{Fe}, \mathrm{Cu}, \mathrm{Zn}$, and $\mathrm{Pb}$.

\section{Phytochemicals analysis of unfermented and fermented castor seeds}

The qualitative and quantitative analysis of alkaloids, tannins, saponins, and flavonoids were determined by using the methods of Trease and Evans (2005), Sofowora (1993), Harborne and Baxter (1995), and Trease and Evans (2005). Briefly, for alkaloids, the sample was stirred with $5 \mathrm{ml}$ of $10 \%$ aqueous hydrochloric acid in a hot water bath, and a few drops of Dragendoff's reagent was added. The occurrence of orange-red crystalline precipitate indicated the presence of alkaloids. Saponin, $5 \mathrm{~g}$ of the sample was grounded, and $10 \mathrm{ml}$ of $20 \%$ aqueous ethanol was added. The mixture was stirred continuously for 4 hours in a hot water bath at about $55^{\circ} \mathrm{C}$. The mixture was filtered, and the residue was re-extracted using $20 \%$ ethanol. The concentrate was transferred into a $250 \mathrm{~mL}$ separating funnel, and $20 \mathrm{ml}$ of diethyl ether was added and shaken together. The aqueous layer was recovered, while the ether was later discarded. The purification process was repeated. $60 \mathrm{ml}$ of n-butanol was added and washed twice with $10 \mathrm{ml}$ of 5\% aqueous $\mathrm{NaCl}$ (Obadoni and Ochuko 2001). Saponin content was calculated as:

\section{$\%$ Saponin $=\underline{\text { Initial weight }- \text { final weight of the sample }} \times 100$ Initial weight}

Flavonoid was quantified by boiling $5 \mathrm{~g}$ of each processed sample in $100 \mathrm{ml}$ of $2 \mathrm{M} \mathrm{HCl}$ solution for 40 mins. It was allowed to cool to room temperature before filtered through Whatman filter paper. A flavonoid in the filtrate was precipitated by drop-wise addition of concentrated ethyl acetate until in excess. Following filtration, the flavonoid precipitate recovered was ovendried, and the weight of flavonoid was obtained by difference and expressed as a percentage of the sample analyzed (Obadoni and Ochuko 2001).

Tannin was determined by adding $40 \mathrm{ml}$ diethyl ether containing $1 \%$ acetic acid (v/v) to $400 \mathrm{mg}$ of each sample. The mixtures were mixed to remove pigment materials. The supernatant was carefully discarded after 5 mins, and $20 \mathrm{ml}$ of $70 \%$ aqueous acetone was added. The flask was sealed with a cotton plug covered with aluminum foil, then kept in a shaker for 2 hours for extraction. The flask content was filtered through the Whatman filter paper (No. 2). Aliquot $0.5 \mathrm{ml}$ filtrate was made up to $1.0 \mathrm{ml}$ with distilled water and $0.5 \mathrm{ml}$ Folin Ciocalteu reagent added and then mixed properly before $2.5 \mathrm{ml}$ of $20 \%$ sodium carbonate solution was added and further mixed. The mixtures were kept for 40 mins at room temperature, after which absorbance was taken using a spectrophotometer, and concentration was estimated from the tannic acid standard curve (Sarkiyayi and Agar 2010).

The concentration of phenolics in the sample was determined using the spectrophotometric method at $\lambda \max =$ $765 \mathrm{~nm}$ (Singleton et al. 1999). The reaction mixture was prepared by mixing $0.5 \mathrm{ml}$ of a methanolic solution of the sample, $2.5 \mathrm{ml}$ of $10 \%$ Folin-Ciocalteu's reagent dissolved in water, and $2.5 \mathrm{ml}$ of $7.5 \% \mathrm{NaHCO}_{3}$. Blank was concomitantly prepared, containing $0.5 \mathrm{ml}$ methanol, 2.5 $\mathrm{ml} 10 \%$ Folin-Ciocalteu's reagent dissolved in water, and $2.5 \mathrm{ml}$ of $7.5 \%$ of $\mathrm{NaHCO}_{3}$. After that, the samples were $\mathrm{t}$ incubated at $45^{\circ} \mathrm{C}$ for $45 \mathrm{~min}$. The samples were prepared in triplicate for each analysis, and the mean value of absorbance was obtained. The same procedure was repeated for the standard solution of gallic acid, and the calibration line was constructed. Based on the measured absorbance, the concentration of phenolics was determined $(\mathrm{mg} / \mathrm{ml})$ from the calibration curve. The phenolics content in extracts was expressed in terms of gallic acid equivalent (mg of GA/g of extract).

\section{Determination of amino acids in unfermented and fermented castor seeds}

Initially, $200 \mathrm{mg}$ of each ground seed sample was defatted with a chloroform/methanol mixture in a ratio of 1: 1 . Then, $30 \mathrm{mg}$ of the defatted sample was put into a glass ampoule, added $7 \mathrm{ml}$ of $6 \mathrm{M} \mathrm{HCl}$, and oxygen was expelled by passing nitrogen into the ampoule. The sealed ampoule was put in the oven at $105^{\circ} \mathrm{C}$ for 22 hours, allowed to cool, and filtered. The filtrate was then evaporated to dryness at $40^{\circ} \mathrm{C}$ under vacuum in a rotary evaporator. The residue was dissolved with $5 \mathrm{ml}$ acetate buffer ( $\mathrm{pH}$ 2.0) and loaded into the amino acid analyzer, where the amino acid compositions of the seed samples were determined by the Ion Exchange Chromatographic (IEC) method using the Technicon Sequential Multisample Amino Acid Analyzer (Technicon Instruments Corporation, New York) (Spackman et al. 1958).

\section{Experimental design for in vivo animal model}

Twenty albino rats were procured from the Department of Animal Production and Health Science, Federal University of Technology, Akure, Nigeria. The rats were weighed and divided into four groups. They were fed on a basal diet and water for seven days before being fed a different diet. The rats were grouped as follows: (i) BD: Animal fed basal diet only, (ii) BD+UCS: Animal fed basal diet and ground unfermented castor seed, (iii) BD+CSF: Animal fed basal diet and commercial fermented castor seeds ("Ogiri"), (iv) BD+CPF: Animal fed basal diet and castor seed fermented with Pleurotus ostreatus. The 
feeding trials were carried out for ten days before the rats were sacrificed.

\section{Collection of blood sample}

Blood samples were collected by direct cardiac puncture and dispensed into EDTA bottles. The blood samples collected were tested for the red blood cell (RBC) counts, White Blood Cell (WBC) counts, hemoglobin ( $\mathrm{Hb})$ concentration, and Packed Cell Volume (PCV) according to the method described by Chesbrough (2000).

\section{Histopathological analysis}

Histopathological examination was carried out according to Sarkar et al. (2005). Briefly, the liver and kidneys were dissected and fixed instantaneously in $10 \%$ formal saline for 24 hours. The specimens were washed under tap water, dehydrated in ascending grades of ethanol, cleared in xylene, and embedded in paraffin wax (melting point of $50-56{ }^{\circ} \mathrm{C}$ ). Paraffin sections were cut at six $\mu \mathrm{m}$ thicknesses using a rotary microtome; the sections were stained with Harris hematoxylin and eosin. An automatic photomicrographic system made the observation using a light microscope, and photographs were taken.

\section{Statistical analysis}

Data obtained from the study were subjected to analysis of variance (ANOVA) using statistical software, SPSS version 22.0 , and judged significantly at a $95 \%$ confidence level $(\mathrm{P}<0.05)$.

\section{RESULTS AND DISCUSSION}

\section{Proximate and mineral composition of the unfermented and fermented castor seeds}

Castor seeds fermented with Pleurotus ostreatus (CPF) had the highest protein content of $20.47 \%$, while CSF had the highest moisture content of $17.29 \%$. UCS had the highest ash (6.02\%), fats (6.65\%), and fiber (6.62\%) (Figure 1). Table 1 shows the mineral composition of raw and fermented castor seeds. CPF had the highest magnesium composition of $7.16 \mathrm{mg} / \mathrm{g}$. CSF had the highest zinc of 0.69 $\mathrm{mg} / \mathrm{g}$. UCS had the highest calcium of $0.30 \mathrm{mg} / \mathrm{g}$.

\section{Phytochemical constituents of the unfermented and fermented castor seeds}

There was no significant difference $(p<0.05)$ in the tannin content of CSF $(0.06 \mathrm{mg} / \mathrm{g})$ and CPF $(0.05 \mathrm{mg} / \mathrm{g})$. There was a significant increase $(\mathrm{p}<0.05)$ in the alkaloid $(7.40 \mathrm{mg} / \mathrm{g})$ and saponin contents $(6.69 \mathrm{mg} / \mathrm{g})$ of CPF There was a slightly significant difference in the phenol contents of the unfermented and fermented samples: UCS $(1.30 \mathrm{mg} / \mathrm{g}), \mathrm{CSF}$, and CPF $(1.20 \mathrm{mg} / \mathrm{g})$. There were significant differences in flavonoid contents of the samples: UCS $(0.65 \mathrm{mg} / \mathrm{g})$, CSF $(0.60 \mathrm{mg} / \mathrm{g})$ and CPF $(0.48 \mathrm{mg} / \mathrm{g})$.

\section{Amino acid concentration of the unfermented and fermented castor seeds}

Table 3 revealed the amino acids in the unfermented (UCS) and fermented castor seeds (CSF and CPF). Tryptophan was absent in UCS but had values of $0.78 \mathrm{mg} / \mathrm{g}$ and $1.15 \mathrm{mg} / \mathrm{g}$ in $\mathrm{CSF}$ and $\mathrm{CPF}$, respectively. Glutamic acid had the highest concentration in all the samples: UCS had a composition of $10.02 \mathrm{mg} / \mathrm{g}$, CSF had a composition of $10.22 \mathrm{mg} / \mathrm{g}$, and CPF had a composition of $14.59 \mathrm{mg} / \mathrm{g}$. Glutamine and asparagine were absent in all the samples.

\section{Hematological studies of the albino rats were used to test for the safety of the unfermented and fermented castor seeds}

Hematological analysis of the rats was tested for safety for unfermented and fermented castor seeds. Rats fed commercial fermented castor seeds $(\mathrm{BD}+\mathrm{CSF})$ had the highest Packed Cell Volume (PCV) of $30.67 \%$, while rats fed raw castor seeds (BD+UCS) had the lowest PCV of $16.33 \%$. Rats fed castor seeds fermented with Pleurotus ostreatus (BD+CPF) had the highest White Blood Cell (WBC) of $5.43 \mathrm{~g} / \mathrm{L}$, while rats fed raw castor seeds (BD+UCS) had the lowest WBC of $3.33 \mathrm{~g} / \mathrm{L}$. Rats fed basal diet (BD) had the highest Red Blood Cell (RBC) of $3.42 \mathrm{~g} / \mathrm{L}$, while rats fed raw castor seeds (BD+UCS) had the lowest RBC of $1.66 \mathrm{~g} / \mathrm{L}$. Rats fed basal diet (BD) had the highest hemoglobin levels of $10.47 \mathrm{~g} / \mathrm{L}$, while rats fed raw castor seeds (BD+UCS) had the lowest hemoglobin level of $4.47 \mathrm{~g} / \mathrm{L}$. Table 5 shows the differential White Blood Cell Count of rats tested for biosafety. BD+ UCS group had the highest lymphocyte count of $59.33 \%$, while the BD group had the lowest lymphocyte count, highest neutrophil (46.67\%), eosinophil $(2.00 \%)$, and monocyte $(2.00 \%)$ count. BD+CPF group had no count for neutrophils, eosinophils, and monocyte. All the groups had no basophil count.

Histopathological studies of the albino rats were used to test for the safety of the unfermented and fermented castor seeds

Figure 2 shows the photomicrograph of the kidneys of rats used to test for biosafety of the raw and fermented castor seed. Kidney of rats fed basal diet (BD) and kidneys of rats fed commercial fermented castor seed (BD+CSF) had the normal histological structure showing the glomerulus, Bowman's capsule, and lymphatic vessels (LV). The kidney of rats fed raw castor seed (BD+UCS) showed enlargement of Bowman's capsule (EBC), shrunken glomerulus (SG), and distorted proximal and distal convoluted tubules $(\mathrm{Z})$. The kidneys of rats fed castor seed fermented with Pleurotus ostreatus (BD+CPF) showed disruption of glomerular tuft (D) and hemorrhagic lesions (I). Figure 3 shows the photomicrograph of livers of rats fed raw and fermented castor seeds. Liver of rats fed basal diet and liver of rats fed fermented castor seed showed normal liver structure of sinusoid cells $(\mathrm{O})$ and hepatocytes $(\mathrm{N})$. The liver of rats fed raw castor seed showed dilation of the sinusoid cells $(\mathrm{T})$ and vascular congestion (K). The liver of rats fed castor seeds fermented with Pleurotus ostreatus showed dilation of the sinusoid cells (T), vascular congestion $(\mathrm{K})$, and degenerated hepatocytes (DH). 
Table 1. Mineral composition (mg/g) of unfermented and fermented castor seeds

\begin{tabular}{lccc}
\hline Minerals & UCS & CPF & CSF \\
\hline Lead & $0.03 \pm 0.00^{\mathrm{b}}$ & $0.02 \pm 0.00^{\mathrm{a}}$ & $0.02 \pm 0.00^{\mathrm{a}}$ \\
Zinc & $0.13 \pm 0.00^{\mathrm{a}}$ & $0.38 \pm 0.00^{\mathrm{b}}$ & $0.69 \pm 0.00^{\mathrm{c}}$ \\
Iron & $0.17 \pm 0.00^{\mathrm{a}}$ & $0.75 \pm 0.00^{\mathrm{c}}$ & $0.36 \pm 0.00^{\mathrm{b}}$ \\
Nickel & $0.03 \pm 0.00^{\mathrm{c}}$ & $0.01 \pm 0.00^{\mathrm{b}}$ & $0.00 \pm 0.00^{\mathrm{a}}$ \\
Chromium & $0.01 \pm 0.01^{\mathrm{b}}$ & $0.00 \pm 0.00^{\mathrm{a}}$ & $0.00 \pm 0.00^{\mathrm{a}}$ \\
Magnesium & $3.79 \pm 0.01^{\mathrm{a}}$ & $7.16 \pm 0.00^{\mathrm{c}}$ & $6.86 \pm 0.01^{\mathrm{b}}$ \\
Manganese & $0.04 \pm 0.00^{\mathrm{a}}$ & $0.21 \pm 0.00^{\mathrm{c}}$ & $0.21 \pm 0.00^{\mathrm{c}}$ \\
Copper & $0.10 \pm 0.00^{\mathrm{a}}$ & $0.21 \pm 0.00^{\mathrm{c}}$ & $0.19 \pm 0.00^{\mathrm{b}}$ \\
Calcium & $0.30 \pm 0.00^{\mathrm{b}}$ & $0.10 \pm 0.00^{\mathrm{a}}$ & $0.10 \pm 0.00^{\mathrm{a}}$ \\
\hline
\end{tabular}

Note: Values carrying the same alphabet in the same row are not significantly different $(p>0.05)$. Values are means of triplicates \pm SD. UCS: Unfermented castor seeds, CPF: Castor seeds fermented with Pleurotus ostreatus, CSF: Commercial fermented castor seeds

Table 2. Quantitative phytochemical compositions (mg/g) of unfermented and fermented castor seeds

\begin{tabular}{cccc}
\hline Parameters & UCS & CPF & CSF \\
\hline *Phenol & $1.30 \pm 0.01^{\mathrm{b}}$ & $1.20 \pm 0.00^{\mathrm{a}}$ & $1.20 \pm 0.01^{\mathrm{a}}$ \\
Tannin & $0.10 \pm 0.01^{\mathrm{b}}$ & $0.05 \pm 0.00^{\mathrm{a}}$ & $0.06 \pm 0.01^{\mathrm{a}}$ \\
Alkaloids & $0.99 \pm 0.01^{\mathrm{a}}$ & $7.40 \pm 0.01^{\mathrm{c}}$ & $1.90 \pm 0.01^{\mathrm{b}}$ \\
Flavonoids & $0.65 \pm 0.01^{\mathrm{c}}$ & $0.48 \pm 0.01^{\mathrm{a}}$ & $0.60 \pm 0.01^{\mathrm{b}}$ \\
Saponins & $1.95 \pm 0.01^{\mathrm{b}}$ & $6.69 \pm 0.01^{\mathrm{c}}$ & $1.40 \pm 0.01^{\mathrm{a}}$ \\
\hline
\end{tabular}

Note: Values carrying the same alphabet in the same row are not significantly different $(p>0.05)$. Values are means of triplicates \pm SD. UCS: Unfermented castor seeds CPF: Castor seeds fermented with Pleurotus ostreatus CSF: Commercial Fermented castor seed, *expressed in terms of Gallic acid equivalent (mg of $\mathrm{GA} / \mathrm{g}$ of extract)
Table 3. Amino acid composition ( $\mathrm{mg} / \mathrm{g}$ ) of unfermented and fermented castor seeds

\begin{tabular}{|c|c|c|c|}
\hline Amino acids & UCS & CSF & CPF \\
\hline Leucine & $6.55 \pm 0.26^{\mathrm{a}}$ & $7.58 \pm 0.02^{b}$ & $9.92 \pm 0.02^{\mathrm{c}}$ \\
\hline Lysine & $4.49 \pm 0.10^{\mathrm{b}}$ & $3.71 \pm 0.02^{\mathrm{a}}$ & $5.62 \pm 0.02^{\mathrm{c}}$ \\
\hline Phenylalanine & $2.60 \pm 0.15^{\mathrm{a}}$ & $3.97 \pm 0.02^{\mathrm{b}}$ & $4.61 \pm 0.02^{\mathrm{c}}$ \\
\hline Isoleucine & $1.64 \pm 0.20^{\mathrm{a}}$ & $3.81 \pm 0.01^{\mathrm{b}}$ & $4.30 \pm 0.02^{\mathrm{c}}$ \\
\hline Tryptophan & $0.00 \pm 0.00^{\mathrm{a}}$ & $0.78 \pm 0.03^{b}$ & $1.15 \pm 0.01^{\mathrm{c}}$ \\
\hline Valine & $2.73 \pm 0.20^{\mathrm{a}}$ & $3.97 \pm 0.01^{\mathrm{b}}$ & $3.97 \pm 0.02^{\mathrm{b}}$ \\
\hline Methionine & $0.62 \pm 0.03^{\mathrm{a}}$ & $0.87 \pm 0.01^{\mathrm{b}}$ & $2.03 \pm 0.03^{\mathrm{c}}$ \\
\hline Proline & $2.96 \pm 0.10^{\mathrm{b}}$ & $2.35 \pm 0.02^{\mathrm{a}}$ & $4.06 \pm 0.02^{c}$ \\
\hline Arginine & $4.67 \pm 0.18^{\mathrm{a}}$ & $5.31 \pm 0.02^{\mathrm{a}}$ & $8.52 \pm 0.03^{\mathrm{b}}$ \\
\hline Tyrosine & $1.85 \pm 0.05^{\mathrm{a}}$ & $2.77 \pm 0.02^{\mathrm{b}}$ & $4.32 \pm 0.02^{c}$ \\
\hline Histidine & $1.57 \pm 0.11^{\mathrm{a}}$ & $2.36 \pm 0.02^{\mathrm{c}}$ & $2.22 \pm 0.02^{\mathrm{b}}$ \\
\hline Cystine & $0.73 \pm 0.08^{\mathrm{a}}$ & $0.97 \pm 0.02^{b}$ & $1.20 \pm 0.01^{\mathrm{c}}$ \\
\hline Alanine & $2.58 \pm 0.35^{\mathrm{a}}$ & $3.87 \pm 0.02^{b}$ & $4.32 \pm 0.02^{\mathrm{c}}$ \\
\hline Glutamic acid & $10.00 \pm 0.12^{\mathrm{a}}$ & $10.22 \pm 0.02^{\mathrm{b}}$ & $14.59 \pm 0.02^{\mathrm{c}}$ \\
\hline Glycine & $1.26 \pm 0.29^{\mathrm{a}}$ & $3.52 \pm 0.02^{b}$ & $3.95 \pm 0.01^{\mathrm{c}}$ \\
\hline Threonine & $1.56 \pm 0.01^{\mathrm{a}}$ & $3.02 \pm 0.02^{\mathrm{b}}$ & $4.15 \pm 0.01^{c}$ \\
\hline Serine & $3.32 \pm 0.38^{\mathrm{b}}$ & $2.32 \pm 0.00^{\mathrm{a}}$ & $3.62 \pm 0.00^{\mathrm{b}}$ \\
\hline Aspartic acid & $7.69 \pm 0.15^{\mathrm{a}}$ & $7.81 \pm 0.03^{\mathrm{a}}$ & $12.59 \pm 0.01^{b}$ \\
\hline Glutamine & $0.00 \pm 0.00^{\mathrm{a}}$ & $0.00 \pm 0.00^{\mathrm{a}}$ & $0.00 \pm 0.00^{\mathrm{a}}$ \\
\hline Asparagine & $0.00 \pm 0.00^{\mathrm{a}}$ & $0.00 \pm 0.00^{\mathrm{a}}$ & $0.00 \pm 0.00^{\mathrm{a}}$ \\
\hline
\end{tabular}

Note: Values carrying the same superscript in the same row are not significantly different $(p>0.05)$. Values are means of triplicates \pm SD UCS: Unfermented castor seeds CPF: Castor seeds fermented with Pleurotus ostreatus CSF: Commercial fermented castor seeds.

Table 4. Hematological parameters of rats fed unfermented and fermented castor seeds

\begin{tabular}{lllll}
\hline Groups & PCV $(\%)$ & Hb $(\mathbf{g} / \mathbf{L})$ & WBC $\left(\mathbf{1 0}^{\mathbf{9}} \mathbf{g} / \mathbf{L}\right)$ & $\mathbf{R B C}\left(\mathbf{1 0} \mathbf{1}^{\mathbf{1 2}} \mathbf{g} / \mathbf{L}\right)$ \\
\hline BD+UCS & $16.33 \pm 1.53^{\mathrm{a}}$ & $4.47 \pm 0.31^{\mathrm{a}}$ & $3.33 \pm 0.21^{\mathrm{a}}$ & $1.66 \pm 0.03^{\mathrm{a}}$ \\
BD+CSF & $30.67 \pm 1.15^{\mathrm{c}}$ & $8.43 \pm 0.35^{\mathrm{c}}$ & $4.30 \pm 0.30^{\mathrm{b}}$ & $2.23 \pm 0.15^{\mathrm{b}}$ \\
BD+CPF & $22.00 \pm 0.00^{\mathrm{b}}$ & $7.47 \pm 0.15^{\mathrm{b}}$ & $5.43 \pm 0.31^{\mathrm{c}}$ & $2.49 \pm 0.10^{\mathrm{c}}$ \\
BD & $31.67 \pm 1.53^{\mathrm{c}}$ & $10.47 \pm 1.15^{\mathrm{d}}$ & $4.17 \pm 0.15^{\mathrm{b}}$ & $3.42 \pm 0.66^{\mathrm{d}}$ \\
\hline
\end{tabular}

Note: Values carrying the same alphabet in the same column are not significantly different $(\mathrm{p}>0.05)$. Values are means of triplicates \pm SD BD: Fed basal diet only, BD+UCS: Fed basal diet mixed with ground unfermented castor seeds, BD+CSF: Fed basal diet mixed with commercial fermented castor seeds, BD+CPF: Fed basal diet mixed with castor seed fermented with Pleurotus ostreatus.

Table 5. Differential white blood cell count of rats fed unfermented and fermented castor seeds

\begin{tabular}{llllll}
\hline Group & Lymphocytes (\%) & Neutrophil (\%) & Eosinophil (\%) & Monocytes (\%) & Basophil (\%) \\
\hline BD+UCS & $59.33 \pm 1.15^{\mathrm{c}}$ & $38.00 \pm 2.00^{\mathrm{b}}$ & $1.00 \pm 0.00^{\mathrm{b}}$ & $1.00 \pm 0.00^{\mathrm{b}}$ & $0.00 \pm 0.00$ \\
BD+CSF & $48.00 \pm 0.00^{\mathrm{b}}$ & $41.33 \pm 1.15^{\mathrm{c}}$ & $1.67 \pm 0.58^{\mathrm{c}}$ & $1.67 \pm 0.58^{\mathrm{c}}$ & $0.00 \pm 0.00$ \\
BD+CPF & $50.00 \pm 2.00^{\mathrm{b}}$ & $31.33 \pm 1.53^{\mathrm{a}}$ & $0.00 \pm 0.00^{\mathrm{a}}$ & $0.00 \pm 0.00^{\mathrm{a}}$ & $0.00 \pm 0.00$ \\
BD & $46.00 \pm 2.00^{\mathrm{a}}$ & $46.67 \pm 1.15^{\mathrm{d}}$ & $2.00 \pm 0.00^{\mathrm{c}}$ & $2.00 \pm 0.00^{\mathrm{c}}$ & $0.00 \pm 0.00$ \\
\hline
\end{tabular}

Note: Values carrying the same alphabet in the same column are not significantly different $(\mathrm{p}>0.05)$. Values are means of triplicates \pm SD. BD: Fed basal diet only, BD+UCS: Fed basal diet mixed with ground unfermented castor seeds, BD+CSF: Fed basal diet mixed with commercial fermented castor seeds, BD+CPF: Fed basal diet mixed with castor seed fermented with Pleurotus ostreatus 


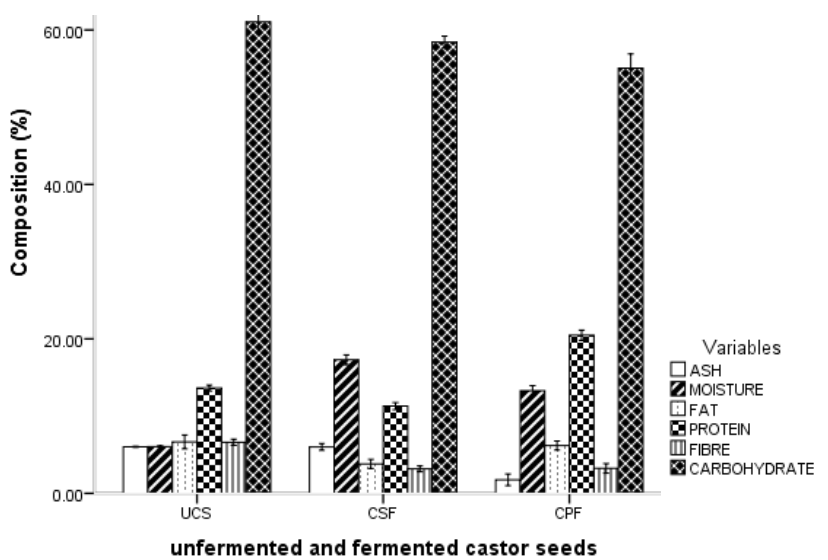

Figure 1. Proximate composition of unfermented and fermented castor seeds. Note: UCS: Unfermented castor seeds, CSF: Fermented castor seeds, CPF: Castor seeds fermented with Pleurotus ostreatus

\section{Discussion}

The proximate analysis revealed that the fermented castor seeds had higher moisture content than the unfermented ones. The increase in the moisture content could be attributed to the moisture absorbed by the seeds during boiling before fermentation. This result agrees with Ishiwu et al. (2015) that the moisture content of the fermented castor seeds increased after fermentation.
However, there was a reduction in the moisture content of castor seeds fermented with Pleurotus ostreatus (CPF) compared to 'Ogiri,' the naturally fermented condiment from castor seeds (CSF). This result agreed with Ajala and Akinterinwa's (2016) findings which evaluated the nutrient quality of dried 'Ogiri' produced from melon seeds. The researchers observed a reduction in the moisture content.

CPF had the highest protein content among the three samples (20.47\%), while CSF had the lowest (11.14\%). This result is in accordance with the findings of Bao et al. (2013), who observed an increase in the protein content (28.17\% to $133.42 \%$ ) of rice fermented with Pleurotus eryngii. The increase in the protein content could be due to leaching out of some soluble substances present in the seeds (tannin, trypsin inhibitor) that are protein-bound (Kpanja et al. 2016). The increase in the protein contents could also be due to the bioconversion of crude fiber and carbohydrates in the unfermented castor seeds into mycelia protein or single-cell protein (Alemawor et al., 2009). Deepalakshmi and Mirunalini (2014) reported that Pleurotus ostreatus are rich in diverse proteins, which possibly enhance the protein contents of $\mathrm{CPF}$, thereby making its protein content higher than others. The findings of Espinosa-Páez et al. (2017) enhanced the protein digestibility of Avena sativa and Phaseolus vulgaris by fermentation with Pleurotus ostreatus.
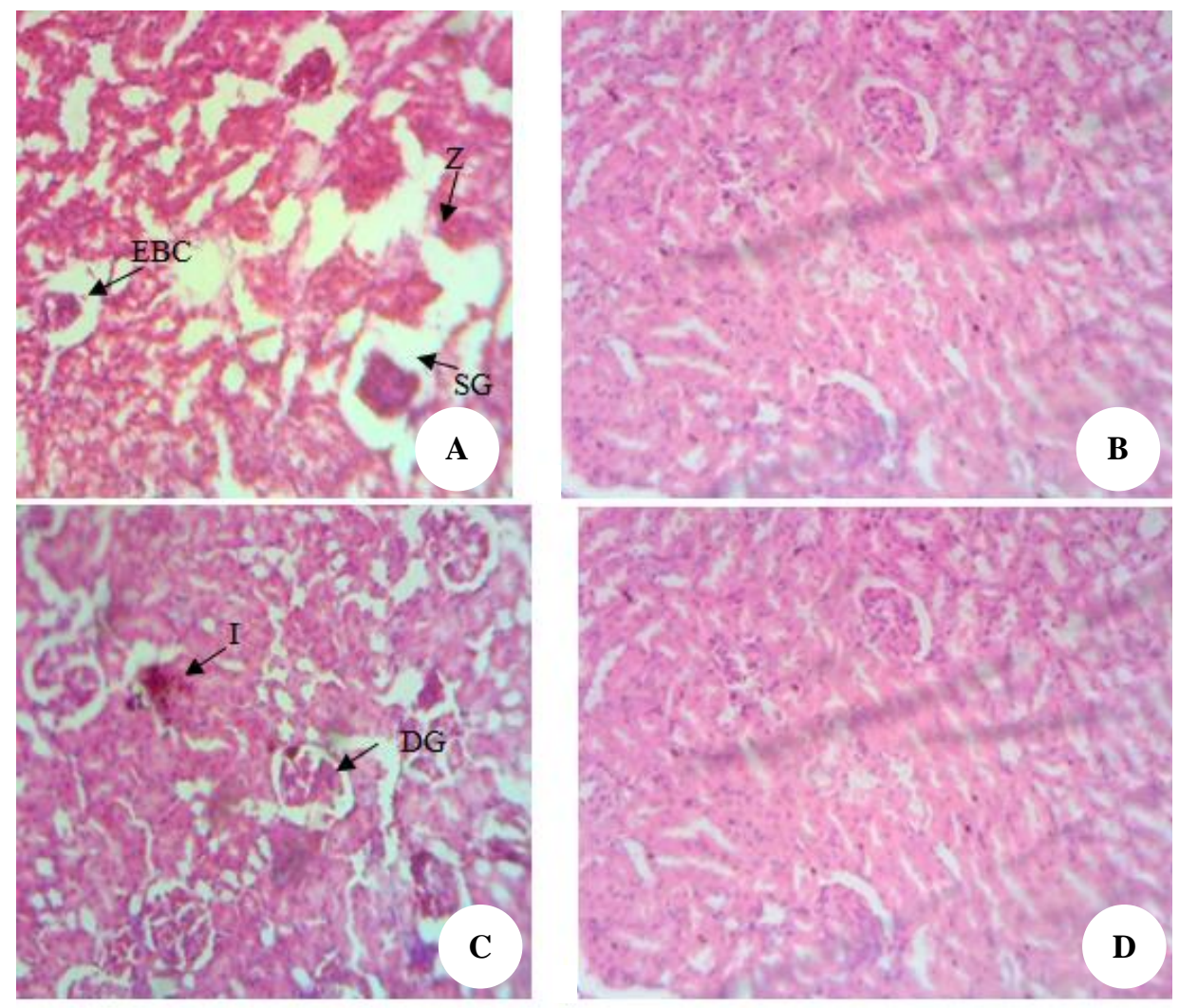

Figure 2. Photomicrograph of kidneys of rats fed unfermented and fermented castor seeds. A: fed raw castor seeds (BD+UCS), B: fed commercial fermented castor seeds (BD+CSF), C: fed castor seeds fermented with Pleurotus ostreatus (BD+CPF), D: fed basal diet (BD). Enlargement of Bowman's capsule (EBC), shrunken glomerulus (SG) and distorted proximal and distal convoluted tubules (Z), disruption of glomerular tuft (D), and hemorrhagic lesions (I). 


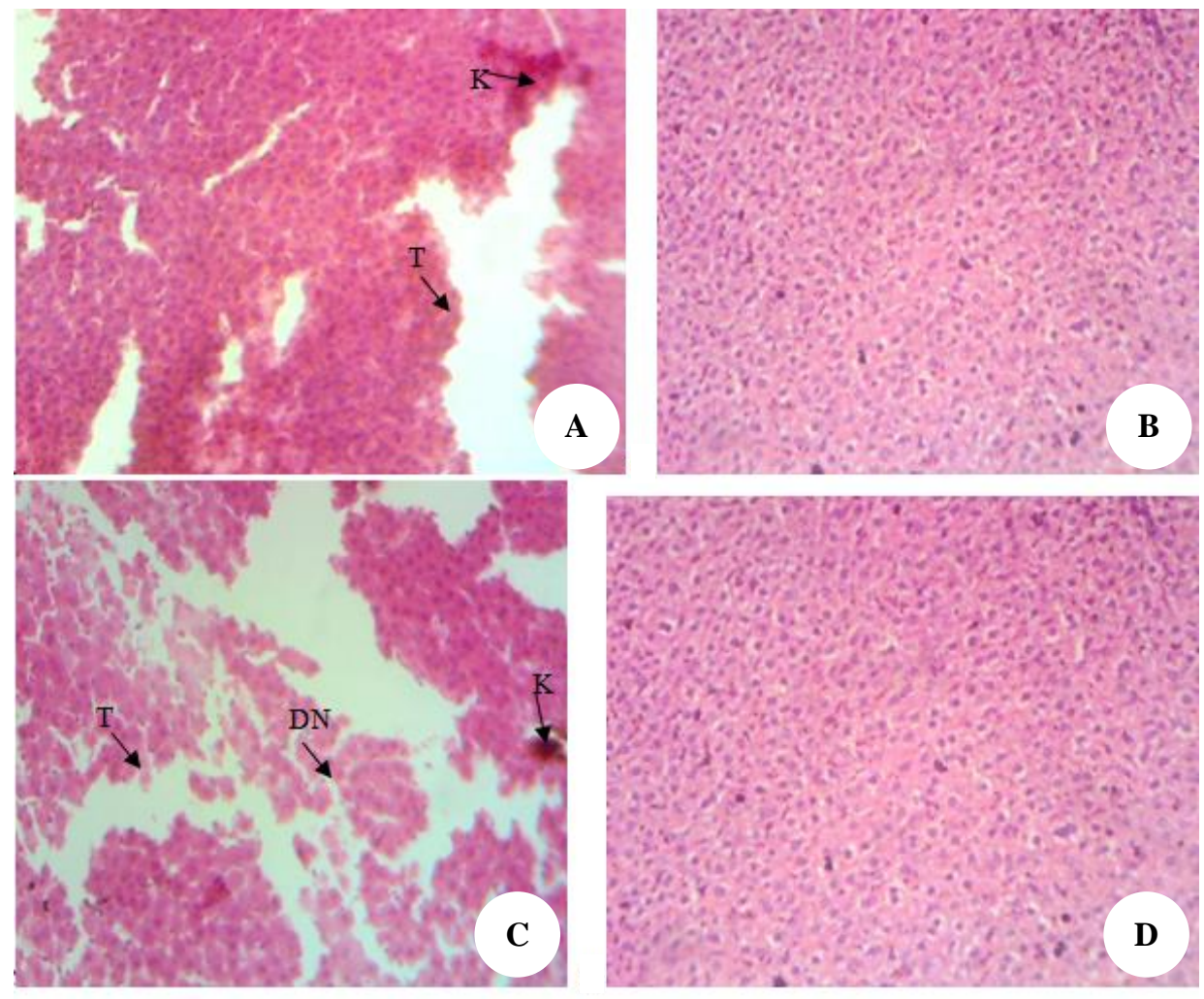

Figure 3. Photomicrograph of livers of rats fed unfermented and fermented castor seeds. A: fed raw castor seeds (BD+UCS), B: fed commercial fermented castor seeds (BD+CSF), C: fed castor seeds fermented with Pleurotus ostreatus (BD+CPF), D: fed basal diet (BD). Dilation of the sinusoid cells (T), degenerated hepatocytes (DN), and vascular congestion (K)

The increase in protein can be attributed to the presence of extracellular enzymes produced by Pleurotus ostreatus, which are proteins in nature (Alemawor et al., 2009; Sherief et al., 2010). These enzymes break down organic complexes to enhance the release and availability of proteins, which could contribute to the high protein content of the Pleurotus ostreatus-fermented castor seeds. The lowest protein content of CSF may be due to leaching during boiling. The lowest protein content may also be caused by the metabolic activities of the proteolytic microorganisms; they used the nitrogen content that contributed to the amount of protein content in the seed, thus, leading to the reduction in the protein contents of the locally fermented castor seeds (Ishiwu et al. 2015).

The fermented castor seeds' fiber contents were lower than the unfermented castor seeds. The lower fiber content could be of medicinal importance. The fiber reduction may be attributed to the ability of the fermenting microfloral to hydrolyze and metabolize castor seed (substrate) as a carbon source to synthesize cell biomass (Madigan et al. 2002). The fat contents in the fermented castor seeds were very low compared to the unfermented castor seeds, which could be attributed to the possible degradation of fat by lipase produced by microorganisms during the fermentation (Kpanja et al. 2016). The fat content in castor seeds deviated from what was reported by Aisha et al. (2013) and Mosquera-Artamonov et al. (2018). This could result from drying castor seed before fermentation and the difference in methods adopted.

The ash content of castor seeds fermented with Pleurotus ostreatus was the lowest compared to UCS and CSF. The reduction of ash content in castor seeds fermented with Pleurotus ostreatus may be due to leaching due to microbial activities that some of the minerals were lost or used (Kpanja et al. 2016). The high ash content of UCS may be due to the high content of minerals present in the seeds, which had been reported by Aisha et al. (2013) when they examined wild castor seeds from the Northern region of Nigeria.

The mineral composition: lead, nickel, chromium, and calcium were reduced in the fermented castor seeds (CSF and CPF) compared to unfermented (UCS). The finding of Ikanone and Oyekan (2014) revealed that boiling might cause the leaching of minerals into water, which may reduce the amount of these minerals in fermented samples. Although, the concentration of zinc, iron, magnesium, manganese, and copper was higher in the fermented castor seeds than in the unfermented castor seeds. This result may be due to releasing these elements from their complex states, thereby making them available in the fermented form (Omodara and Olowomofe 2013). Magnesium had the highest concentration in all the samples (UCS, CSF, and $\mathrm{CPF}$ ); hence fermented castor seeds are a source of magnesium. Magnesium is a highly essential mineral for human growth; it plays an important role in forming teeth 
and bones. In thermoregulation, it regulates calcium balance and acts as an activator of numerous enzyme systems (Dinu et al., 2014).

The phytochemical study of the unfermented and fermented castor seeds revealed the presence of phenol, saponins, alkaloids, flavonoids, and tannins. These phytochemicals in foods of plant origin indicate that they can be used as functional foods and for medicinal benefits (Settharaksa et al., 2012). This study reduced the flavonoid concentration in the fermented castor seeds, with CPF having the lowest concentration. Microbial enzymes, such as glucosidase, amylase, cellulase, tannase, esterase, invertase, or lipase produced during fermentation, are able to hydrolyze glucosides and break down plant cell walls matrix or starch and consequently facilitating the flavonoids extraction (Hur et al. 2014). During fermentation, the $\beta$-glucosidases of microbial origin could also be used to hydrolyze the phenolics and flavonoids (Nazarni et al. 2015), thereby reducing flavonoids.

The tannin concentration was reduced in the fermented castor seeds, with CPF having the lowest concentration (0.05 mg/L). Ejinkeonye et al. (2018) reported a similar trend when raw watermelon seeds were fermented to a local condiment called 'Ogiri.' Rodríguez et al. (2009) revealed that during fermentation, tannic acid degrades into smaller components such as glucose and gallic acid. The microorganisms involved during fermentation may also cause a reduction in tannin. According to Fan et al. (2000) and da Luz et al. (2013), Pleurotus ostreatus can eliminate antinutrients, mainly tannin, by the action of a tannase present in the Pleurotus ostreatus, which ultimately destroys the tannins.

Saponin was reduced in 'Ogiri,' a locally made condiment from castor seeds (CSF), while CPF has the highest concentration. Research carried out by Okwulehie et al. (2018) revealed that Pleurotus ostreatus has a higher content of saponin, which could have led to the high saponin content of CPF. The reduction observed in CSF may result from a long boiling time and fermentation. Heat processing and fermentation reduce phytochemicals/antinutritional concentration in raw food to an acceptable nutritional level (Oranusi et al., 2014).

There was no significant difference in the phenolic content of the UCS, CSF, and CPF. This result indicates that castor seeds and their fermented products are good candidates and sources of phenolic compounds. Phenols are commonly present in foods originating from the plant. Phenols protect plants from oxidative damage (Okwu 2005). It has been highly medicinal for different purposes, specifically blocking enzymes that cause inflammations and modifying the prostaglandin pathways, thereby protecting platelets from clumping (Okwu and Omodamiro 2005). Fermented castor seeds (CPF and CSF) had higher alkaloid content than raw castor seeds. Research carried out by Okwulehie et al. (2018) revealed that Pleurotus ostreatus has high alkaloid content, which may probably be responsible for the increased alkaloid concentration of CPF.

Glutamic acid was the most abundant amino acid, followed by aspartic acid, while glutamine and asparagine were absent in the samples (both raw and fermented samples). This trend corresponds with the observations of Khattab et al. (2009), who observed that glutamic and aspartic acid are the most abundant amino acids in some oilseeds and legumes. During the acid hydrolysis, glutamine and asparagine were converted to glutamic and aspartic acids with the liberation of ammonium $\left(\mathrm{NH}_{4}{ }^{+}\right)$ ions, resulting in the high concentration of glutamic and aspartic acids and also the absence of glutamine and asparagine (Onwuliri and Anekwe 2001). The raw (unfermented) and fermented castor seeds may serve as a good source of monosodium glutamate due to the high concentration of glutamic acid since it is being used as a substrate for a condiment. Monosodium glutamate serves as a major component of food seasonings (Ishiwu et al., 2015). The reduction in protein content may result from boiling time before fermentation, which leads to the leaching of the amino acid content. Heat may lead to Maillard reactions, and subsequent Amadori rearrangements make the protein and its amino acids significantly unavailable (Igwe et al., 2012). It was observed that the total content of tryptophan, methionine, and cysteine as essential amino acids was enhanced after fermentation. The increase may result from the action of the microflora and enzymes, which break down chemical constituents and, thus, enhance the available amino acids (Igwe et al. 2012). Alemawor et al. (2009) reported that Pleurotus ostreatus are rich in essential amino acids, thereby increasing amino acids in CPF. This result agrees with Bao et al. (2013), who reported the nutritional properties of rice with Pleurotus eryngii and found the total content of essential amino acids enhanced after fermentation.

The rats fed UCS and CPF have lower PCV than those fed the basal diet. The decrease in PCV may result from the decreased RBC, which had been earlier reported by Etim et al. (2014). Rats fed CSF had similar PCV to rats fed the basal diet alone. This result suggests that CSF had a positive immunomodulatory effect. The rats fed UCS had the lowest hemoglobin, while the rats fed the basal diet had the highest hemoglobin. The reduced amount of hemoglobin in the groups fed UCS and fermented castor seeds (CPF) may indicate the varying degree of unstable aliment. This result agrees with Ekeh et al. (2010), which observed a reduction in the hemoglobin level of rats drunk with water contaminated with engine oil and suggested that the reduction is due to blood cell deficiency caused by the presence of the toxic substance. The rats fed raw and fermented castor seeds had lower RBCs than those fed the basal diet. The low RBC values may be due to their low hemoglobin concentration. RBCs are mainly made up of hemoglobin, which gives color to RBCs and helps transport oxygen throughout the body (Preet and Prakash 2011). The observed reduction in $\mathrm{RBC}$ may be attributed to the cytotoxic effects of compounds present in the castor seeds (Eyong et al., 2004). The increase in the lymphocyte count in rat-fed castor seeds could have been associated with the body's defense mechanism when exposed to a foreign substance, perhaps the residual compound in castor seeds. Lymphocytes help humoral antibody formation and cellular 
immunity (Aboderin and Oyetayo 2006). Although, there was a relatively increased White Blood Cells (WBC) and lymphocyte count in rats fed fermented castor seeds, which could also suggest that the fermented castor seeds had an immunostimulatory effect because the rats were stable without any impediments observed. Oluwafemi et al. (2016) reported that Pleurotus ostreatus has high nutritional contents, which boosts the immune system of rats since it has been incorporated into the fermented product. The increase in the WBC counts of rat-fed CPF suggests that this group would have greater immunity to infections, thereby having an immunostimulatory effect. This result agrees with Nfambi et al. (2015), who observed an increase in the WBC count of immunosuppressed rats treated with methanolic leaf extracts of Moringa oleifera. There was a decrease in the neutrophil counts of the rats fed UCS, CSF, and CPF compared to the control. It may result from the amount of neutrophils used during sensitization to an antigen (Weber et al., 2015). The significant reduction in the hematological parameters of the rats fed UCS shows the hematotoxicity; a similar effect was reported by Eyong et al. (2004), who observed a significant reduction in the RBC values of rats and rabbits after ingestion of crude oil, an organic molecule containing a toxic compound (aliphatic and aromatic hydrocarbons ), which result in the generation of free radical species in various tissues. In red blood cells, free radicals are known to alter the erythrocyte membrane as well as other cell membranes as a consequence of oxidative stress (Ita and Udofia 2011). The results of the liver histopathology revealed that the control group and CSF had the normal liver structure of healthy rats, which contains several hepatic lobules. Rats fed UCS and CPF had dilated sinusoid cells and degenerated hepatocytes. The kidney of the rats fed basal diet and CSF showed normal histological structures of the glomeruli and renal tubules. The kidneys of rats fed the basal diet, and CSF had normal kidney structure. In contrast, rats fed UCS and CPF showed various defects, such as shrunken glomerulus, hyalinization, enlarged renal tubules, and hemorrhagic lesions. It may be due to the effect of ricin, the toxic compounds present in the seeds. Ricin is quite stable and extremely toxic to the cells of different organs such as the liver, kidney, lung, pancreas, intestine, and thyroid (DaSilva 2003). Ingestion of ricin results in gastrointestinal hemorrhage, necrosis of the liver, spleen, and kidneys; severe localized muscle pain; regional lymph node necrosis, and moderate involvement of visceral organs (Olayioye et al. 2014). This result agreed with Hassan et al. (2015). They reported the effect of the acute phase of toxicity (in different doses) of aqueous extracts of castor seeds on the organs of albino rats. They observed that the internal organs showed degenerative changes and proteinaceous material in the spleen and kidney after 24 hours.

In conclusion, this study revealed that Pleurotus ostreatus was able to degrade the toxic compounds present in castor seeds to a greater extent. The results also revealed that Pleurotus ostreatus helped to enhance the nutritional properties of the fermented castor seeds. Pleurotus ostreatus could be used to detoxify castor seeds on a larger scale and reduce the boiling time of castor seeds before natural fermentation. Pleurotus ostreatus might be used in the detoxification of other poisonous plants.

\section{REFERENCES}

Aboderin FI, Oyetayo VO. 2006. Haematological studies of rats fed with different doses of probiotic, Lactobacillus Plantarum, isolated from fermenting corn slurry. Pak J Nutr 5 (2): 102-106.

Aidoo KE, Nout MJ, Sarkar PK. 2006. Occurrence and function of yeasts in Asian indigenous fermented foods. FEMS Yeast Res 6: 30-39.

Aisha U, Aleiro BL, Shehu K, Hauwa B, Sumayya BI, Shuaibu M, Abubakar MB. 2013. Seed Characteristics and Proximate Analysis of Wild Castor Plant from Sokoto State. J Environ Sci Toxicol Food Technol 3 (4): 59-63.

Ajala AS, Akinterinwa OE. 2016. Quality Evaluation of Tunnel Dried 'Ogiri'. J Biotechnol Res 1 (2): 81-88.

Akande TO, Odunsi AA, Akinfala EO. 2016. A review of nutritional and toxicological implications of castor bean (Ricinus communis L.) meal in animal feeding systems. J Anim Physiol Anim Nutr 100: 201-210.

Alemawor F, Dzogbefia VP, Oddoye EOK, Oldham JH. 2009. Effect of Pleurotus ostreatus fermentation on cocoa pod husk composition: influence of fermentation period and $\mathrm{Mn}^{2+}$ supplementation on the fermentation process. Afr J Biotechnol 8 (9): 1950-1958.

AOAC. 2013. Official Methods of Analysis of AOAC international. 19th edition. AOAC 53 International, Gaithersburg, Maryland, USA.

Bao L, Li Y, Wang Q, Han J, Yang X, Li H, Wang S, Wen H, Li S, Liu H. 2013. Nutritive and Bioactive Components in Rice Fermented with the Edible Mushroom Pleurotus eryngii. Mycol 4 (2): 96-102.

Chesbrough M. 2000. Haematological tests. In: District Laboratory Practice in Tropical Countries (Part 2). Cambridge University Press, Cambridge, pp. 267-347.

da Luz JMR, Paes SA, Torres DP, Nunes MD, da Silva JS, Mantovani HC, Kasuya MCM. 2013. Production of edible mushroom and degradation of antinutritional factors in jatropha biodiesel residues. LWT-Food Sci Technol 50 (2): 575-580.

da Luz JR, Nunes MD, Paes SA, Torres DP, Kasuya MCM. 2014. Biodetoxification of Jatropha curcas Seed Cake by Pleurotus ostreatus. Afr J Microbiol Res 8 (11): 1148-1156.

DaSilva L, Cote D, Roy C, Martinez M, Duniho S, Pitt MLM, Dertzbaugh M. 2003. Pulmonary gene expression profiling of inhaled ricin. Toxicon 41 (7): 813-822.

Deepalakshmi K, Mirunalini S. 2014. Pleurotus ostreatus: An Oyster Mushroom with Nutritional and Medicinal Properties. J Biochem Technol 5 (2): 718-726

Ekeh FN, Ekechukwu NE, Atama CI, Atta IC. 2010. Haematology profile of albino rats given feed and water contaminated with varied concentrations of used engine oil. Anim Res Int 7 (2): 1229 - 1235.

Espinosa-Páez E, Alanis-Guzmán MG, Hernández-Luna CE, BáezGonzález JG, Carlos A, Amaya-Guerra CA, Andrés-Grau AM. 2017. Increasing antioxidant activity and protein digestibility in Phaseolus vulgaris and Avena sativa by Fermentation with the Pleurotus ostreatus Fungus. Molecules 22: 1-11.

Etim NN, Williams ME, Akpabio U, Offiong EEA. 2014. Haematological Parameters and Factors Affecting Their Values. Agric Sci 2 (1): $37-$ 47.

Eyong EU, Umoh IB, Ebong PE, Eteng MU, Antai AB, Akpa AO. 2004. Haematoxic effects following ingestion of Nigerian crude oil and crude oil polluted shellfish by rats. Niger J Physiol Sci 19: 1-6.

Fan L, Pandey A, Mohan R, Soccol CR. 2000. Comparison of coffee industry residues for production of Pleurotus ostreatus in solid state fermentation. Acta Biotechnol 20: 41-52.

Harborne SB, Baxter H. 1995. Phytochemical dictionary: A handbook of bioactive compounds from plants. Taylor and Francis, London.

Hassan IA, Al-Awadi AQ, Salman IS, Jasim NN. 2016. Histological study of the effect of aqueous extraction of the castor seeds on the internal organs in male white mice. Basrah J Vet Res 15 (1): 54-65.

Hur SJ, Lee SY, Kim YC, Choi I, Kim GB. 2014. Effect of Fermentation on the Antioxidant Activity in Plant-Based Foods. Food Chem 160: 346-356. 
Igwe CU, Ojiako OA, Anugweje KC, Nwaogu LA, Ujowundu CO. 2012. Amino acid profile of raw and locally processed seeds of Prosopis africana and Ricinus communis: potential antidotes to protein malnutrition. Funct Food Health Dis 2 (4): 107-119.

Ikanone CEO, Oyekan PO. 2014. Effect of Boiling and Frying on the Total Carbohydrate, Vitamin C and Mineral Contents of Irish (Solanun tuberosum) and Sweet (Ipomea batatas) Potato Tubers. Niger Food J 32 (2): 33-39.

Iljas N, Peng AC, Gould WA. 1973. Tempeh - An Indonesian Fermented Soybean Food. Ohio horticulture Series No. 394, April, Department of Horticulture, Ohio Agricultural Research and Development Centre, Wooster.

Ishiwu CN, Anih JC, Victor-Aduloju AT. 2015. Effect of Period of fermentation on nutrients of castor oil seed (Ricinus communis). Direct Res J Agric Food Sci 3 (10): 178-183.

Ita SO, Udofia UA. 2011. Comparative Study of Some Haematological Parameters in Rats Following Ingestion of Crude Oil (Nigerian Bonny Light), Petrol, Kerosene and Diesel. Asian J Biol Sci 4: 498-505.

Khattab RY, Arntfield SD, Nyachoti CM. 2009. Nutritional Quality of Legume Seeds as Affected by Some Physical Treatments, Part 1: Protein Quality Evaluation. LWT - Food Sci Technol 42 (6): 1107 1112.

Kpanja EJ, Omage JJ, Abubakar H. 2016. Effect of Soaking and Fermentation on the Proximate Composition, Levels of Antinutritional Factors, Oil Quality and Mineral Elements Composition of Castor. J Anim Prod Re, 28 (1): 123-129.

Madeira Jr. JV, Macedo JA, Macedo GA. 2011. Detoxification of castor bean residues and the simultaneous production of tannase and phytase by solid-state fermentation using Paecilomyces variotii. Bioresour Technol 102 (15): 7343-7348.

Madigan TM, Martinko JM, Parker J. 2002. Brock Biology of Microorganisms. 9th ed. Prentice-Hall, New York.

Mosquera-Artamonov JD, Hernandez-Rios I, Mendez-Gallegos SJ, PereaFlores MJ, Peña-Aguilar JM, Rodriguez-Garcia ME. 2018 Physicochemical characteristics of seeds from wild and cultivated castor bean plants (Ricinus communis L.). Ingeniería e Investigación 38 (1): 24-30.

Nazarni R, Purnama D, Umar S, Eni H. 2016. The effect of fermentation on total phenolic, flavonoid and tannin content and its relation to antibacterial activity in jaruk tigarun (Crataeva nurvala, Buch HAM). Int Food Res J 23 (1): 309-315.

Nfambi J, Bbosa GS, Sembajwe LF, Gakunga J, Kasolo JN. 2015. Immunomodulatory activity of methanolic leaf extract of Moringa oleifera in Wistar albino rats. J Basic Clin Physiol Pharmacol 26 (6) 603-611.

Nout MJR, Aidoo KE. 2011. Asian Fungal Fermented Food. In Hofrichter M (eds) Industrial Applications. The Mycota (A Comprehensive Treatise on Fungi as Experimental Systems for Basic and Applied Research), vol 10. Springer, Berlin, Heidelberg.

Obadoni BO, Ochuko PO. 2001. Phytochemical Studies and Comparative Efficacy of the Crude Extracts of some Homostatic Plants in Edo and Delta States of Nigeria. Glob J Pure Appl Sci 8b: 203-208

Ojinnaka MC, Ojimelukwe PC, Ezeama CF. 2013. Changes in Enzyme Activities during the Fermentation of Castor Oil Bean Seeds using $B$ subtilis as Monoculture Starter. Afr J Food Sci Technol 4 (5): 122 128.

Okwu DE, Omodamiro OD. 2005. Effect of Hexane extract and phytochemical content of Xylopia aethiopica and Ocimum gratissimum on uterus of Guinea pig. Bio-Research 3 (2): 40-44.

Okwu DE. 2005. Phytochemicals. Vitamins and Mineral contents of two Nigeria Medicinal Plants. Intl J Mol Med Adv Sci 1: 375-381.

Okwulehie IC, Oti VO, Ikechukwu GC. 2018.Evaluation of the Mycochemical and Proximate Composition of Oyster Mushrooms (Pleurotus ostreatus VAR Florida, (MONT) Singer. and $P$. pulmonarius (FR) QUEL) Grown on Bark of Gmelina arborea Roxb. Straw of Saccharum officinarum L.and Pods of Delonix regia (BOJ. Ex Hook.) RAF. UK J Pharm Biosci 6 (1): 8-15.
Olayioye A, Olaniran OA, Olaifa JI. 2014. Effect of Powdered Castor Oil Seed (Ricinus communis L.) on Some Internal Organs of Albino Rat. Int J Appl Agric Apic Res 10 (1\&2): 98-11.

Oluwafemi GI, Seidu TK, Fagbemi TN. 2016. Chemical Composition, Functional Properties and Protein Fractionation of Edible Oyster Mushroom (Pleurotus ostreatus). Ann Food Sci Technol 17 (1): 218223.

Omafuvbe BO, Olumuyiwa SF, Osuntogu BA, Adewusi RA. 2004. Chemical and Biochemical changes in African Locust Bean (Parkiabiglobosq) and melon (Citrullus vulgaris) seeds During Fermentation to condiments. Pak J Nutr 3 (3): 140-145.

Omodara TR, Olowomofe TO. 2015. Effects of Fermentation on the Nutritional Quality of African Locust Bean and Soybean. Int J Sci Res 4 (1): 1069-1071.

Onwuliri VA, Anekwe GE. 2001. Amino Acids and Other Biochemical Components of Ricinus communis (Variety Minor), an Anticonceptive Seed. Pak J Biol Sci 4 (7): 866-868.

Oranusi S, Okereke IJ, Wesley B, Okorondu SI. 2014. Microbiological and Chemical Compositions of Agbarati and Ogiri Igbo, Popular Foods of South Eastern Nigerians. J Chem Biol Phys Sci 5 (1): 01-09.

Paulová L, Patáková P, Brányik T. 2016. Advanced Fermentation Processes. Eng Asp Food Biotechnol 4: 89-110.

Preet S, Prakash S. 2011. Haematological Profile in Rattus norvegicus During Experimental Cysticercosis. J Parasit Dis 35 (2): 144-147.

Risk Assessment Studies (RAS). 2007. Natural Toxins in Food Plants Centre for Food Safety Food and Environmental Hygiene Department pp: $1-47$.

Rodríguez H, Curiel JA, Landete JM, de las Rivas B, de Felipe FL, Gómez-Cordovés C, Muñoz R. 2009. Food phenolics and lactic acid bacteria. Int J Food Microbiol 132 (2-3): 79-90.

Sarkar B, Chatterjee A, Adhikari S, Ayyappan S. 2005. Carbofuran-and cypermethrin-induced histopathological alterations in the liver of Labeo rohita (Hamilton) and its recovery. J Appl Ichthyol 21 (2): 131-135.

Sarkiyayi S, Agar TM. 2010. Comparative Analysis on the Nutritional and Anti-Nutritional Contents of the Sweet and Bitter Cassava Varieties. Advance Journal of Food Science and Technology. Adv J Food Sci Technol 2 (6): 328-334.

Settharaksa S, Jongjareonrak A, Hmadhlu P, Chansuwan W, Siripongvutikorn S. 2012. Flavonoid, Phenolic Contents and Antioxidant Properties of Thai Hot Curry Paste Extract and Its Ingredients as Affected of $\mathrm{pH}$, Solvent Types and High Temperature. Int Food Res J 19 (4): 1581-1587.

Sherief AA, El-Tanash AB, Temraz AM. 2010. Lignocellulolytic Enzymes and Substrate Utilization During Growth and Fruiting of Pleurotus ostreatus on Some Solid Wastes. J of Environ Sci Technol 3: 18-34.

Singh D, Patel S, Nag MK, Daharwal SJ, Singh MR. 2013. Plant Toxins: An Overview. Res J Pharmacol Pharmacodyn 5 (5): 283-288.

Singleton VL, Orthofer R, Lamuela-Raventos RM. 1999. Analysis of Total Phenols and Other Oxidation Substrates and Antioxidants by Means of Folin-Ciocalteu Reagent. Method Enzymol 299: 152-178.

Sofowora A. 1993. medicinal plants and traditional medicine in African. Spectrum Book Ltd., Ibadan, Nigeria.

Sousa NL, Cabral GB, Vieira PM, Baldoni AB, Aragão FJ. 2017. Biodetoxification of ricin in castor bean (Ricinus communis L.) seeds. Sci Rep 7 (1): 15385.

Spackman DH, Stein WH, Moore S. 1958. Automatic recording apparatus for use in the chromatography of amino acids. Anal Chem 30: 11901206

Trease GE, Evans MC. 2005. Pharmacognosy. 14th ed. Elsevier, New Delhi, India, p. 53, 431 and 512

Weber FC, Németh T, Csepregi JZ, Dudeck A, Roers A, Ozsvári B, Martin SF. 2015. Neutrophils are required for both the sensitization and elicitation phase of contact hypersensitivity. J Exp Med 212 (1): $15-22$. 